\title{
DYNAMICS OF SOIL NUTRIENTS AND STOICHIOMETRY IN MONGOLIAN SCOTS PINE (PINUS SYLVESTRIS VAR. MONGOLICA) PLANTATION, IN A SEMIARID AREA OF CHINA
}

\author{
KHAN, A. ${ }^{1,2,3}-$ ZHANG, X. ${ }^{2}-$ YANG, X. ${ }^{2^{*}}-$ ZHANG, K. ${ }^{3^{*}}-$ HAYAT, M. ${ }^{3}-\mathrm{XU}, \mathrm{S}^{2}{ }^{2}-$ \\ MUHAMMAD, J. ${ }^{4}-$ SAEED, S. ${ }^{5}-$ SHAH, S. ${ }^{5}-$ IQBAL, S. ${ }^{3}$ \\ ${ }^{I}$ Department of Forestry, Shaheed Benazir Bhutto University, Sheringal, Dir (U), Pakistan \\ (e-mail: alamgir.forester@gmail.com (Khan, A.)) \\ ${ }^{2}$ Institute of Desertification Studies, Chinese Academy of Forestry, Beijing 100091, China \\ (e-mail: zhangxiao978@caf.ac.cn (Zhang,X.),xsxkytjl@163.com (Xu,S.))
}

${ }^{3}$ School of Soil and Water Conservation, Beijing Forestry University, Beijing 100083, China (e-mail: muhammadhayat66@gmail.com (Hayat, M.), sundasiqbal90@gmail.com (Iqbal, S.))

${ }^{4}$ Department of Environmental Science, Shaheed Benazir Bhutto University, Sheringal, Dir (U), Pakistan

(e-mail: juma@sbbu.edu.pk(Muhammad, J.))

${ }^{5}$ Department of Forestry and Wildlife management, University of Haripur, Haripur 22620, Pakistan

(e-mail:Sajjad_saeed222@yahoo.com (Saeed,S.),shah@uoh.edu.pk (Shah,S.))

*Corresponding authors

e-mail:yangxh@caf.ac.cn; phone: 86-10-62824087; fax: 86-10-62889007 (Yang, X.); e-mail: ctccd@126.com; phone: 86-133-6665-5775 (Zhang, K.)

(Received 22 $2^{\text {nd }}$ Nov 2020; accepted $8^{\text {th }}$ Feb 2021)

\begin{abstract}
The aim of this study was to investigate about soil nutrients and stoichiometric ratio in Mongolian scots pine plantation forests. Our results showed that along 5 depth increments $(0-20,20-40,40-60,60-80$, and $80-100 \mathrm{~cm}$ ), the concentration and storage of total soil organic carbon (TSOC), total nitrogen (TN), and total phosphorous (TP) decrease. A significantly higher TSOC, TN, and TP concentration and storage was recorded at $0-20 \mathrm{~cm}$, indicating that more $\mathrm{C}, \mathrm{N}$, and $\mathrm{P}$ were found in the upper soil profile. Similarly, the C:N and C: P stoichiometry and soil TSOC concentrations were significantly higher than soil N:P and $\mathrm{TN}$ and TP concentrations, indicating that coniferous plantation forests store more $\mathrm{C}$ compared to $\mathrm{N}$ and $\mathrm{P}$. TSOC, TN, and TP $(\mathrm{p}<0.01)$ concentrations and storage were positively correlated at depth of $0-20$ and $20-40 \mathrm{~cm}$, showing a relatively constrained C:N:P ratio in this plantation forest. Furthermore, stand density, basal area, and total biomass carbon affected TSOC, TN, and TP concentration. Our findings provide key references to further research studies in Mongolian scots pine plantation regarding TSOC, TN, as well as $\mathrm{TP}$ and their variations and storage along other parameters (tree age, soil texture, ground flora, seasons etc.) at the Research Station of Liaoning Institute of Sand-fixation and Afforestation (42॰420 N, $122 \circ 290$ E, $220.67 \mathrm{~m}$ above sea level), Zhanggutai region, Liaoning Province, southeastern Horqin sandy region, China. Keywords: plantation forests, stand characteristics, depth increment, stoichiometric traits, Horqin sandy land
\end{abstract}

\section{Introduction}

Soil nutrients play an important role in plant growth and development and are essential in vegetation succession, nutrient cycling and ecological management of terrestrial ecosystems ( $\mathrm{Li}$ et al., 2017a), among which carbon (C) is the basic structural element of plant and contributes one-half of the plants biomass (Yang et al., 2007a,b; Kim et al., 2011; 
Sardans et al., 2011). Nitrogen (N) is an essential component of plants and the majority of which are completely dependent on soil $\mathrm{N}$ due to lacking of symbiotic bacteria that fix the $\mathrm{N}$ (Li et al., 2017a), while phosphorous (P) affects photosynthetic assimilation and dry mass in plants (Ågren et al., 2012) and represents the basic element of DNA, RNA and ATP. The lackage of these nutrient elements can limit the plants growth and development (Kim et al., 2011). The amount and concentration of these nutritional elements and their stoichiometry in plants reveal nutrient uptake, utilization ability and adaptation to the environment during different growth stages (Wright and Westoby, 2003; Yang and Luo, 2011).

In plantation forests, variation in nutrient concentrations with stand developmental stages have attracted attention due to their importance for the development of nutrient management practices (Sardans et al., 2011; Yang et al., 2014). So, the relationship between tree growing stages and soil nutrient concentrations based studies provide a basic information regarding management of plantation forests. Many studies have been conducted on variation and distribution of SOC, N, and P along the stand characteristics, and variation in these elements have been ascribed to the fact that the forest stand can potentially vary these nutrients through the amount and decomposition of litter, canopy composition, roots uptake and basal area (Yuan et al., 2013; Xia et al., 2015; Jiang et al., 2017). As an integrative approach that involves the study of different nutrientional elements in ecological relations and involves determining elemental engagements of living organisms ( $\mathrm{Li}$ et al., 2017a), nutritional stoichiometry is affected by ecological conditions (elevation, preciptation, and temperature), plantation age and sampling time (Han et al., 2005; Sardans et al., 2011). It has been reported that SOC, N, and P are strongly correlated with the stand characteristics, soil texture and topography too (Jiang et al., 2017). Therefore, the determination of $\mathrm{C}, \mathrm{N}$, and $\mathrm{P}$ dynamics with stand characteristics and development and soil depth can facilitate the quantification of the pattern and distribution of $\mathrm{C}: \mathrm{N}: \mathrm{P}$ stoichoimetry in the plantation forest ecosystem. Furthermore, it is not clear whether C, N, and $\mathrm{P}$ concentrations and its stoichoimetric ratios in plants are controlled over time, stand characteristics and ecological factors in plantation forests.

In arid and semi-arid regions of China, currently much attention has been given on large scale afforestation and reforestation of degraded land, such as that related with "Grain for Green" and "Three Norths Shelter Forest Systems" Projects. Mongolian scots pine (Pinus sylvestris var. mongolica), only one recommended needle-leaved tree species, had been planted at large-scale in these programs for windbreak and sand stabilization in these regions (Zhang et al., 2019). Despite of the fact that Mongolian pine plantation in these regions has a great role in the combating desertification and controlling land degradation, this plantation forest ecosystem is also acting as carbon, nitrogen, and phosphorous sinks. There is a dire need to study the variation of nutrients in the study area, not only because of the fact that the average soil nutrients concentrations and storage are lower in semi-arid area of China than the global mean, resulting from low nutrients input due to water runoff and soil erosion (Cao and Chen, 2017; Zhang et al., 2017), but also because in semi-arid areas of China the growth of vegetation is restricted due to limited water resources (Chen et al., 2008; Deng et al., 2016). So far fewer information about the role of stand characteristics and depth increment on TSOC, TN, and TP budget in arid and semi-arid areas of China is available, especially in the study area. Thus, this study was conducted with the overall objectives of: 1) to estimate the changes in TSOC, TN, and TP concentration and storage along the depth increment; 2) to determine the TSOC, TN, and TP stoichiometry and their characteristics and nutrients limitations in soil; and, 3) to investigate the effect of stand characteristics on TSOC, TN, and TP concentration and their storage in the Scots Pine 
plantation forests. We hope that this study will be a baseline for further studies in monitoring and mapping of TSOC, TN, and TP in Mongolian Scots pine plantation forests.

\section{Materials and methods}

\section{Description of the study area}

The study was conducted in 2017 at the Research Station of Liaoning Institute of Sandfixation and Afforestation ( $42^{\circ} 420 \mathrm{~N}, 122^{\circ} 290 \mathrm{E}, 220.67 \mathrm{~m}$ above sea level), located in Zhanggutai region, Liaoning Province, southeastern Horqin sandy region, China (Fig. 1). The climate of the area is a typical temperate with continental monsoon, with the mean annual temperature of $7.7^{\circ} \mathrm{C}$ (for 1954-2010) and mean annual precipitation of $474 \mathrm{~mm}$ that mostly (67\%) occur during June-August (Song et al., 2016; Zhang et al., 2019). The area faces approximately three times more annual evaporation than the precipitation, with the annual frost-free period of 150-160 days. The geography is categorized by distribution of sand dunes with low-lying land affected by wind erosion. The key soil category is Aeolian sandy soil (89.4\%). In 1954, an experimental based trial plantation of Mongolian Scots pine was introduced and planted in this region. Here a large number of Mongolian Scots pine plantation forests with different densities, diameter and age ars intersected by other woody plants like Populus L. Pinus tabuliformis Carr and Ulmus pumila L. Understory vegetation includes Setaria viridis (L.), Cleistogenes squarrosa (Trin.) Keng, Eragrostis pilosa (L.) Setaria viridis, Elymus dahuricus Turcz, Geranium wilfordii Maxim, Lespedeza bicolor and Portulaca oleracea L (Zhang et al., 2019).

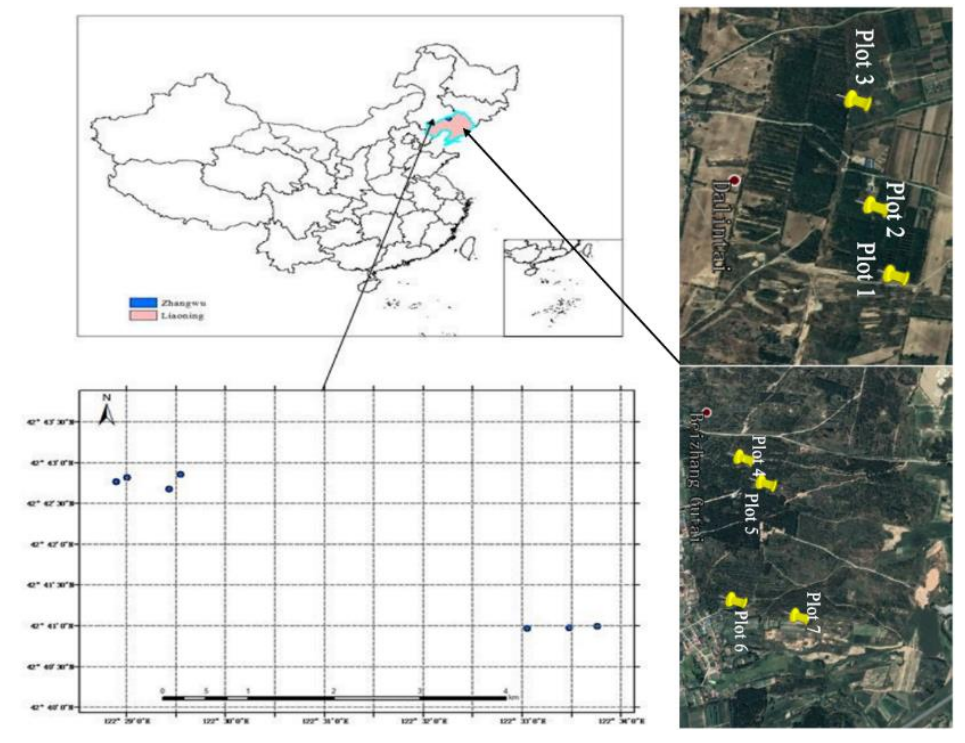

Figure 1. Location of the study area in China

\section{Stand survey and soil sampling and analysis}

7 sites were selected with different stand age and density (Table 1). In each site $50 \mathrm{~m} \times 50 \mathrm{~m}$ standard plot was setup and then stand variables as diameter at breast height $(\mathrm{DBH})$, height (H), stand density (SD), basal area (BA), and tree cross sectional area (CS) in sample plots were measured (Fig. 2). 
Table 1. Stand characteristics and location of Mongolian Scots Pine (Pinus sylvestris var mongolica) plantation forests

\begin{tabular}{|c|c|c|c|c|c|c|c|c|c|c|c|c|c|c|c|}
\hline \multirow[b]{2}{*}{$\begin{array}{l}\text { Plot } \\
\text { No }\end{array}$} & \multirow[b]{2}{*}{ Location } & \multirow[b]{2}{*}{$\begin{array}{l}\text { Altitude } \\
\quad \text { (m) }\end{array}$} & \multirow{2}{*}{$\begin{array}{c}\text { Total } \\
\text { Density } \\
\left(\text { ha }^{-1}\right)\end{array}$} & \multirow[b]{2}{*}{$\begin{array}{c}\text { Mean Diameter } \\
(\mathrm{cm})\end{array}$} & \multirow[b]{2}{*}{$\begin{array}{c}\text { Mean Height } \\
\text { (m) }\end{array}$} & \multicolumn{5}{|c|}{ pH } & \multicolumn{5}{|c|}{ Bulk Density $\left(\mathrm{g} / \mathrm{cm}^{3}\right)$} \\
\hline & & & & & & $\begin{array}{l}\text { O-20 } \\
\text { (cm) }\end{array}$ & $\begin{array}{c}20-40 \\
(\mathrm{~cm})\end{array}$ & $\begin{array}{r}40-60 \\
(\mathrm{~cm})\end{array}$ & $\begin{array}{c}60-80 \\
(\mathrm{~cm})\end{array}$ & $\begin{array}{c}\text { 80-100 } \\
(\mathrm{cm})\end{array}$ & $\begin{array}{l}\mathbf{0 - 2 0} \\
\text { (cm) }\end{array}$ & $\begin{array}{r}20-40 \\
(\mathrm{~cm})\end{array}$ & $\begin{array}{c}40-60 \\
(\mathrm{~cm})\end{array}$ & $\begin{array}{r}60-80 \\
(\mathrm{~cm})\end{array}$ & $\begin{array}{c}\text { 80-100 } \\
(\mathrm{cm})\end{array}$ \\
\hline 1 & $\begin{array}{l}42.6832^{\circ} \mathrm{N}, \\
122.5627^{\circ} \mathrm{E}\end{array}$ & 204.3 & $700 \pm 35.16$ & $19.5 \pm 9.38$ & $9.23 \pm 3.04$ & 5.86 & 6.42 & 6.44 & 6.26 & 6.76 & 1.54 & 1.56 & 1.58 & 1.57 & 1.55 \\
\hline 2 & $\begin{array}{l}42.6828^{\circ} \mathrm{N} \\
122.5579^{\circ} \mathrm{E}\end{array}$ & 204.3 & $572 \pm 21.54$ & $19.55 \pm 3.04$ & $10.61 \pm 1.03$ & 5.48 & 6.39 & 6.57 & 6.46 & 6.4 & 1.50 & 1.59 & 1.53 & 1.55 & 1.56 \\
\hline 3 & $\begin{array}{l}42.6827^{\circ} \mathrm{N} \\
122.5508^{\circ} \mathrm{E}\end{array}$ & 197.3 & $248 \pm 12.52$ & $20.15 \pm 2.88$ & $10.19 \pm 0.89$ & 6.34 & 6.45 & 6.74 & 6.57 & 6.32 & 1.59 & 1.58 & 1.59 & 1.60 & 1.60 \\
\hline 4 & $\begin{array}{l}42.7127^{\circ} \mathrm{N} \\
122.4815^{\circ} \mathrm{E}\end{array}$ & 247.5 & $244 \pm 11.33$ & $22.97 \pm 3.78$ & $11.07 \pm 1.05$ & 5.9 & 8.26 & 6.67 & 6.68 & 6.77 & 1.55 & 1.53 & 1.58 & 1.60 & 1.61 \\
\hline 5 & $\begin{array}{l}42.7137^{\circ} \mathrm{N}, \\
122.4833^{\circ} \mathrm{E}\end{array}$ & 225.5 & $312 \pm 12.30$ & $23.02 \pm 4.31$ & $13.45 \pm 11.30$ & 5.73 & 6.59 & 6.69 & 6.85 & 6.59 & 1.59 & 1.58 & 1.57 & 1.57 & 1.56 \\
\hline 6 & $\begin{array}{l}42.7112^{\circ} \mathrm{N}, \\
122.4904^{\circ} \mathrm{E}\end{array}$ & 235.4 & $364 \pm 17.60$ & $16.69 \pm 3.00$ & $7.95 \pm 0.98$ & 6.36 & 6.55 & 6.72 & 6.75 & 6.7 & 1.59 & 1.56 & 1.56 & 1.56 & 1.59 \\
\hline 7 & $\begin{array}{l}42.7143^{\circ} \mathrm{N}, \\
122.4924^{\circ} \mathrm{E}\end{array}$ & 230.4 & $608 \pm 62.13$ & $9.81 \pm 1.60$ & $4.18 \pm 0.56$ & 6.16 & 6.52 & 6.53 & 6.87 & 6.94 & 1.63 & 1.63 & 1.61 & 1.58 & 1.56 \\
\hline
\end{tabular}

Note: Values are mean \pm standard deviation 


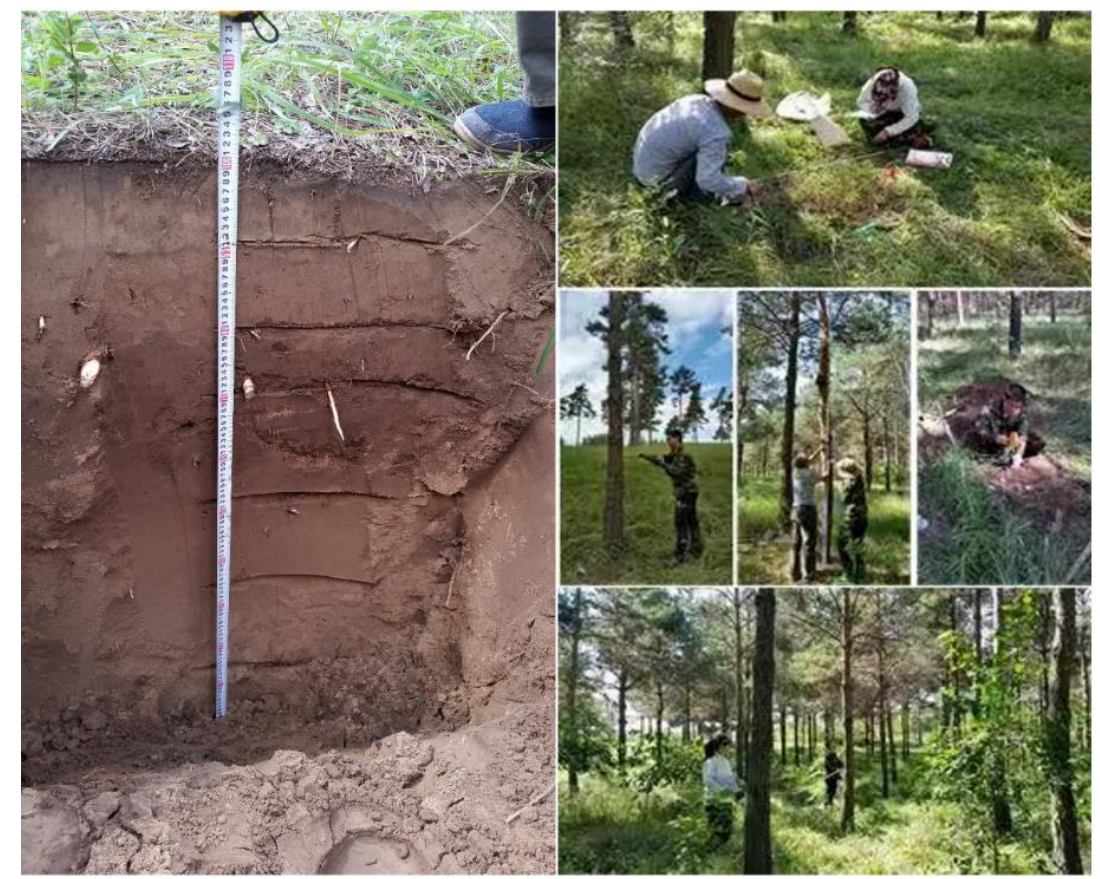

Figure 2. Sampling/experimental design, site habitat and data collection

In each sample plot, the soil samples at five depth levels $(0-20 \mathrm{~cm}, 20-40 \mathrm{~cm}, 40-60 \mathrm{~cm}$, $60-80 \mathrm{~cm}$ and $80-100 \mathrm{~cm}$ ) (Fig. 2) were collected using a steel core (dimensions $=5 \mathrm{~cm}$ ) and were packed and brought to a laboratory for further analysis (Nelson and Sommers, 1982; Bremner, 1996). All the soil samples were sieved through a $2 \mathrm{~mm}$ wire mesh after removing the litter plant roots and stones, and ovened for 24 hours at $105^{\circ} \mathrm{C}$ and the dry weight of each sample was measured. Soil $\mathrm{pH}$ value was measured using FE20 pH meter (Mettler Toledo, Shanghai, China) at soil-to-water (deionized) 2:2.5. $\mathrm{K}_{2} \mathrm{Cr}_{2} \mathrm{O}_{7} / \mathrm{H}_{2} \mathrm{SO}_{4}$ method, a Semimicro-Kjeldhl method and sodium hydroxide $(\mathrm{NaOH})$ fusion and $\mathrm{Mo}-\mathrm{Sb}$ colorimetric method were applied to determine SOC, N, and P respectively (Ouyang et al., 2017).

\section{Stand and soil parameter calculation}

Soil bulk density

Soil bulk density (SD) $\left(\mathrm{g} \mathrm{cm}^{-3}\right)$ of each sample at the respective depth was calculated as:

$$
\mathrm{pb}=\mathrm{M}_{\mathrm{s}} / \mathrm{V}_{\mathrm{t}}
$$

where; $\rho b$ is the bulk density of the soil $\left(\mathrm{g} \mathrm{cm}^{-3}\right), M_{s}(g)$ is an oven-dry mass and $V_{t}$ is the core volume $\left(\mathrm{cm}^{-3}\right)$.

\section{Stand density, basal area and biomass carbon}

Stand basal area was calculated from the calculated stand density and cross sectional area of each tree at respective diameter following Equation 2 (Ahmad et al., 2018)

$$
B A=S D \times C S
$$


where, BA is the basal area $\left(\mathrm{m}^{2} \mathrm{ha}^{-1}\right)$, SD is the stand density $\left(\mathrm{ha}^{-1}\right)$, and CS is the cross sectional area of each tree.

For calculating the above and below ground biomass the experimental model was used for different organs (stem, branch, foliage, and root) of Mongolian Scots pine (Xing et al., 2017). To determine the carbon stock for tree layers, the total carbon concentration was used to the biomass estimates in the different stand diameter classes, then summed up and scaled on the basis of total area $\left(\mathrm{ha}^{-1}\right)$. For calculation of carbon concentration, following Equation 3 was used (Hoover, 2008; Lorenz and Lal, 2010).

$$
\mathrm{Cc}=\mathrm{B} \times \rho_{c}
$$

where $\mathrm{Cc}$ is carbon concentration $\left(\mathrm{Mg} \mathrm{ha}^{-1}\right)$ and $\mathrm{B}$ is biomass $\left(\mathrm{Mg} \mathrm{ha}^{-1}\right), \rho_{c}$ is conversion factor as 0.5 .

$T S O C, T N$, and TP

Following equations were used to calculate the mass storage per area $\left(\mathrm{Mg} \mathrm{ha}^{-1}\right)$ of TSOC $\left(\mathrm{C}_{\mathrm{S}}\right)$, TN $\left(\mathrm{N}_{\mathrm{S}}\right)$, and TP $\left(\mathrm{P}_{\mathrm{S}}\right)$ for each individual soil profile (Ouyang et al., 2017).

$$
\begin{aligned}
\mathrm{C}_{\mathrm{s}} & =\sum_{\mathrm{i}}^{\mathrm{n}}\left[\mathrm{D}_{\mathrm{i}} \times \mathrm{TSOC}_{\mathrm{i}} \times \mathrm{BD}_{\mathrm{i}} \times\left(1-\mathrm{G}_{\mathrm{i}}\right) / 100\right] / 100 \\
\mathrm{~N}_{\mathrm{s}} & =\sum_{\mathrm{i}}^{\mathrm{n}}\left[\mathrm{D}_{\mathrm{i}} \times \mathrm{TN}_{\mathrm{i}} \times \mathrm{BD}_{\mathrm{i}} \times\left(1-\mathrm{G}_{\mathrm{i}}\right) / 100\right] / 100 \\
\mathrm{P}_{\mathrm{S}} & =\sum_{\mathrm{i}}^{\mathrm{n}}\left[\mathrm{D}_{\mathrm{i}} \times \mathrm{TP}_{\mathrm{i}} \times \mathrm{BD}_{\mathrm{i}} \times\left(1-\mathrm{G}_{\mathrm{i}}\right) / 100\right] / 100
\end{aligned}
$$

where $\mathrm{n}$ is the number of soil layers; $\mathrm{i}$ is the ith soil layer; $T S O C_{i}, T N_{i}$, and $T P_{i}$ are the TSOC, TN, and TP concentrations $\left(\mathrm{g} \mathrm{kg}^{-1}\right)$ in the $i$ th soil layer, respectively. Similarly, $B D_{i}, G_{i}$ and $D_{i}$ are the soil bulk density $\left(\mathrm{g} \mathrm{cm}^{-3}\right)$, the proportion $(\%)$ of coarse (> $\left.2 \mathrm{~mm}\right)$ fragments, and the thickness $(\mathrm{cm})$ in the ith layer, respectively. In our study, TSOC, TN, and TP were calculated for depth of $100 \mathrm{~cm}$, divided in to five soil layers $(0-20,20-40$, 40-60, 60-80, and 80-100 cm).

\section{Statistical analysis}

Soil $\mathrm{pH}$, soil bulk density $\left(\mathrm{g} \mathrm{cm}^{-3}\right)$, TSOC $\left(\mathrm{t} \mathrm{ha}^{-1}\right), \mathrm{TN}\left(\mathrm{t} \mathrm{ha}^{-1}\right)$, TP $\left(\mathrm{t} \mathrm{ha}^{-1}\right), \mathrm{C}: \mathrm{N}, \mathrm{C}: \mathrm{P}$, and N:P were tested with soil profile layers by using ANOVA. Similarly, stand density $\left(\mathrm{ha}^{-1}\right)$, basal area $\left(\mathrm{ha}^{-1}\right)$, and total biomass carbon $\left(\mathrm{t} \mathrm{ha}^{-1}\right)$ were fitted with $\mathrm{TN}\left(\mathrm{t} \mathrm{ha}^{-1}\right)$, TSOC $\left(\mathrm{t} \mathrm{ha}^{-1}\right)$, TP $\left(\mathrm{t} \mathrm{ha}^{-1}\right), \mathrm{C}: \mathrm{N}, \mathrm{C}: \mathrm{P}$, and $\mathrm{N}: \mathrm{P}$ as regression analysis (polynomial cubic). All the statistical analysis was performed using statistical software packages Statistix 8.1 and SigmaPlot 12.5 .

\section{Results}

\section{Variation in soil pH and bulk density along the depth increment}

Depth increment and interaction affected the soil $\mathrm{pH}$ but there was no significant effect on bulk density value along depth (Fig. 3A,B). Soil pH was found statistically lower in 0-20 cm layer, while no significant difference among the other layers was recorded (Fig. 3A). The bulk density showed no significant change with increasing depth (Fig. 3B). 

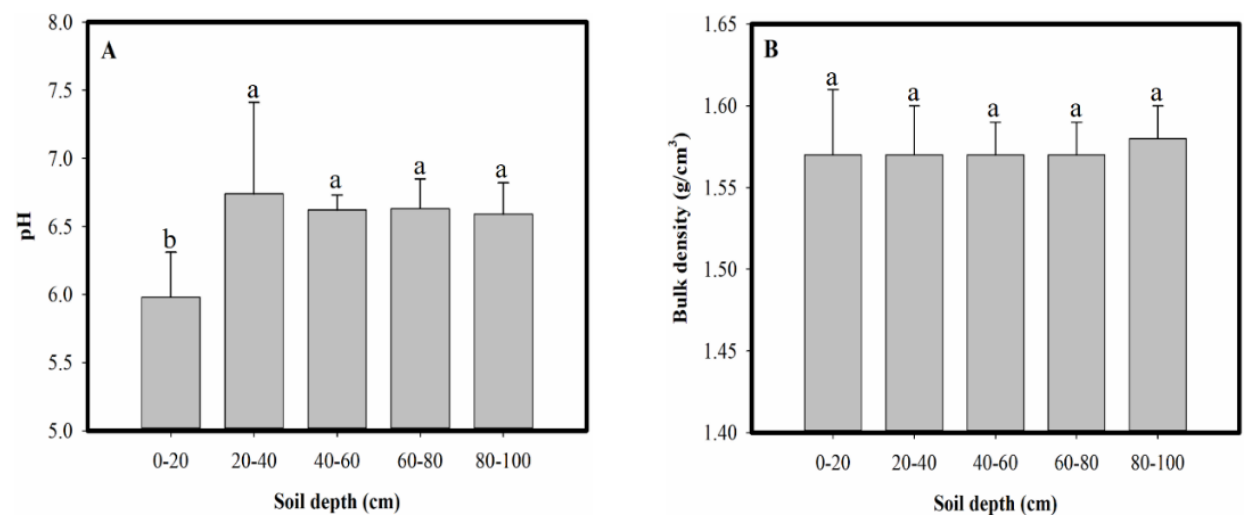

Figure 3. Mean values of soil pH (a) and bulk density (b) along the depth increment. Values are mean \pm standard deviation, different alphabets on each error bar denote the significant differences $(p<0.01, n=7)$ at a given soil depth

\section{Variation in soil TSOC, TN, and TP along the depth increment}

The results showed that the soil TSOC, TN, and TP followed a decreasing trend with the depth increment (Fig. 4). Among the different layers the maximum values for TSOC, TN, and TP storage was found in $0-20 \mathrm{~cm}$ layer. The results presented in Fig. 4 revealed that a significantly higher TSOC, TN, and TP storage occurred at the first layer increment $(0-20 \mathrm{~cm})$. Nevertheless, there was slight or no significant variation in their values among the other layers.
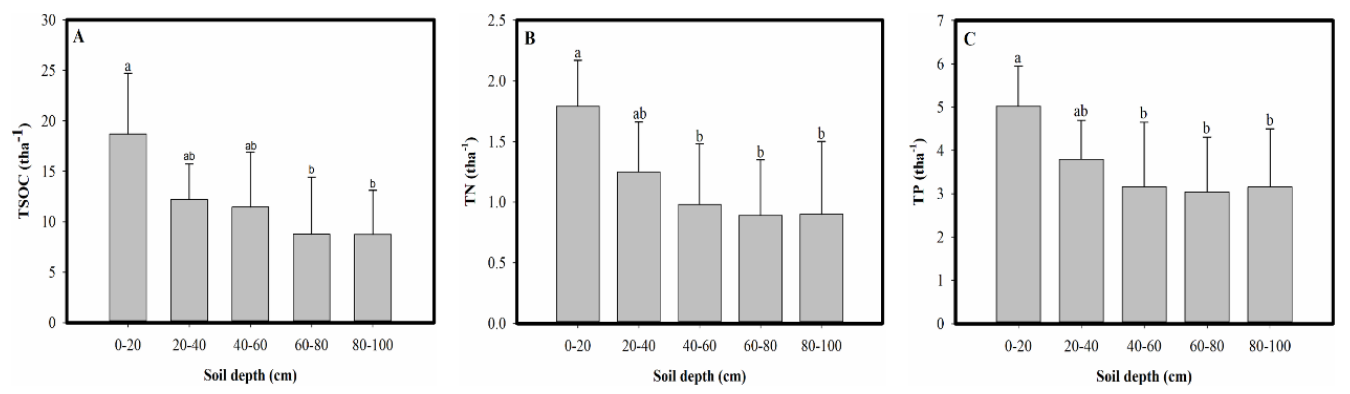

Figure 4. Mean values of total soil organic carbon $\left(t h a^{-1}\right)(a)$, total nitrogen $\left(t h a^{-1}\right)(b)$ and total phosphorous $\left(t \mathrm{ha}^{-1}\right)(\mathrm{c})$ along the depth increment. TSOC, TN, and TP indicate the total

soil organic carbon, total nitrogen, and total phosphorous. Values are mean \pm standard deviation, different alphabets on each error bar denote the significant differences $(p<0.01$, $n=7)$ at a given soil depth

\section{Variation in soil $C: N, C: P$, and $N: P$ ratios along the depth increment}

Fig. 5 showed the values of C:N, C:P, and N:P along the depth. Results of the figure highlighted that among all the depths, $\mathrm{C}: \mathrm{N}$ and $\mathrm{C}: \mathrm{P}$ showing no significant variation, however, the highest $\mathrm{C}: \mathrm{N}$ was found in 40-60 cm layer and lowest in 20-40 cm (Fig. 5A). Similarly, the maximum C:P was recorded in 0-20 cm layer while it was minimum in 80-100 cm layer (Fig. 5B). In contrast to C:N and C:P, a significant variation in the N:P was observed across the depth. A significant larger ration was recorded in the $0-20 \mathrm{~cm}$ and lower in $80-100 \mathrm{~cm}$ layer. However, no significant variation was recorded 20-40, 40-60 and 60-80 cm layer for N:P (Fig. 5C). 

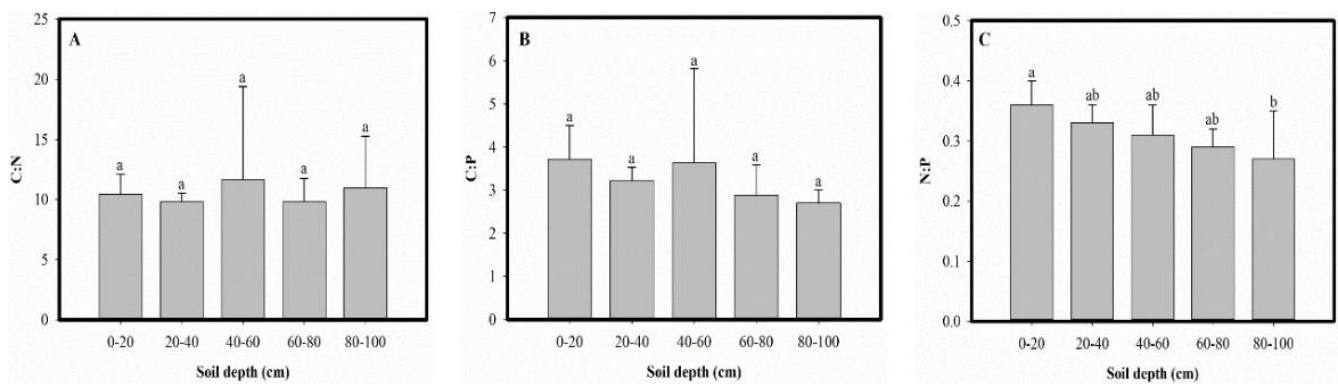

Figure 5. Stoichiometric ratios of soil $C, N$, and $P$ along the depth increment in Mongolian Scots pine plantation. Values are mean \pm standard deviation, different alphabets on each error bar denote the significant differences $(p<0.01, n=7)$ at a given soil depth

\section{Regression analysis (polynomial cubic) between TSOC, TN, and TP with the stand characteristics}

The values of TSOC, TN, and TP were positively correlated with stand different characteristics with $\mathrm{R}^{2}$ value more then 0.5 (Fig. $\left.6 a, b, c\right)$. The relationship of stand density with TSOC, TN and TP was a polynomial cubic. The results of the regression analysis (Fig. 6b) showed that the amount of TN increased with increasing stand density, and reached to a maximum value of $9.48\left(\mathrm{t} \mathrm{ha}^{-1}\right)$ at high stand density of $572\left(\mathrm{ha}^{-1}\right)$. However, a decreasing trend in TN was recorded with increasing density and reached to a minimum value of $4.02\left(\mathrm{t} \mathrm{ha}^{-1}\right)$ at $700\left(\mathrm{ha}^{-1}\right)($ Fig. 6b). Similarly, TP, TSOC followed nearly the same pattern and presented a high value i.e. $26.93\left(\mathrm{t} \mathrm{ha}^{-1}\right)$ (Fig. 6c) and $93.64\left(\mathrm{t} \mathrm{ha}^{-1}\right)$ (Fig. 6a) of TP and TSOC at high density $572\left(\right.$ ha $\left.^{-1}\right)$, respectively.

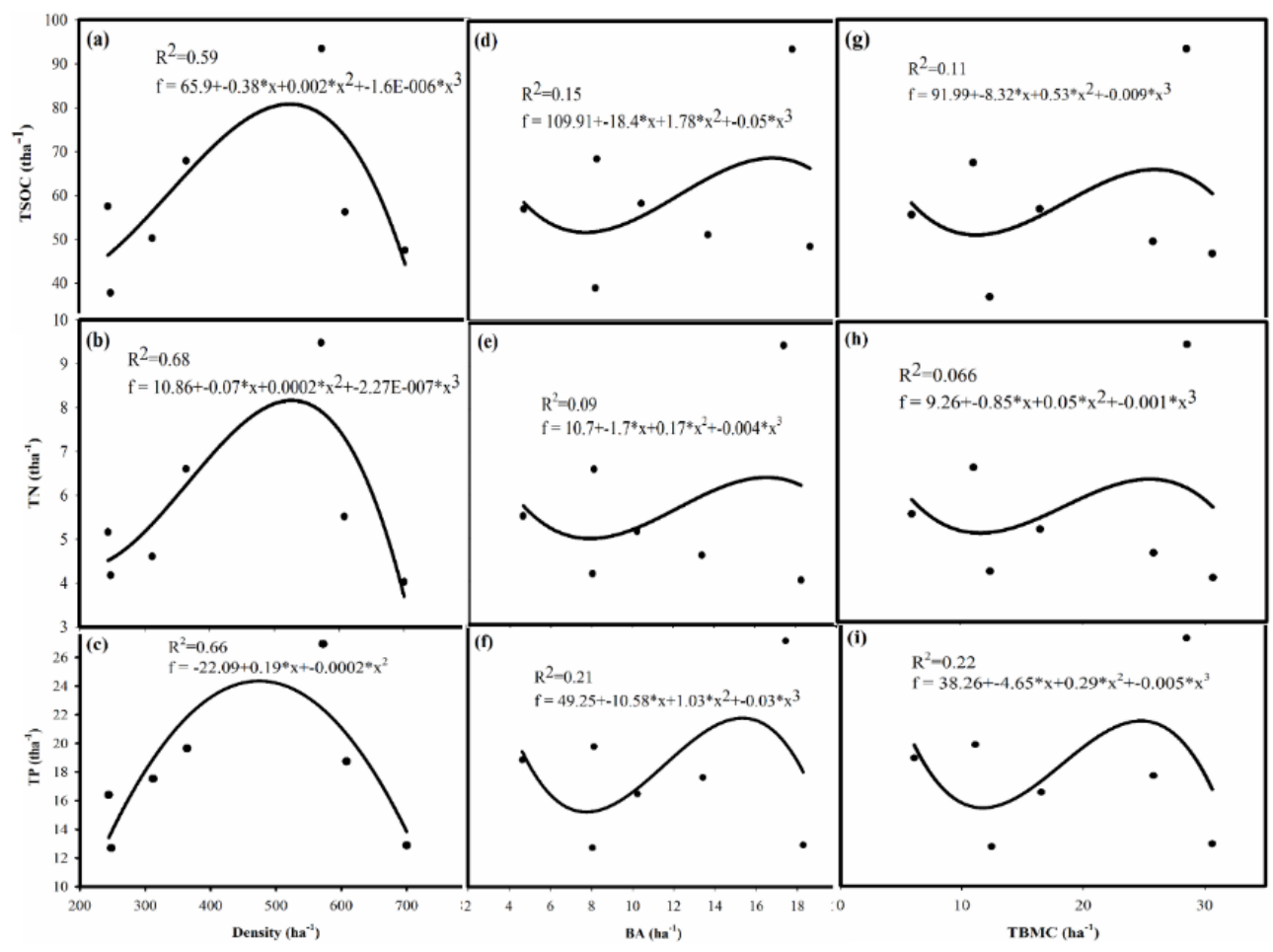

Figure 6. Regression analysis (Polynomial Cubic) of total soil organic carbon (TSOC), total nitrogen (TN), and total phosphorous (TP) with stand density $(a, b, c)$, stand basal area $(d, e, f)$ and total biomass carbon $(g, h, i),(p<0.05, n=7)$ 
Consistently, TSOC, TN and TP though positively correlated with basal area and biomass carbon, but a week (Fig. 6d,e,f,g,h,i) compared to stand density. The amount of TSOC, TN, and TP were found maximum at basal area of $17.43\left(\mathrm{ha}^{-1}\right)$ and minimum at basal area of $18.28\left(\mathrm{ha}^{-1}\right)$ (Fig. 6d,e,f), respectively. Similarly, the amount of TSOC, TN, and TP was recorded higher at biomass carbon of $28.52\left(\mathrm{t} \mathrm{ha}^{-1}\right)$ and lower at biomass carbon of $30.63\left(\mathrm{t} \mathrm{ha}^{-1}\right)$ (Fig. $\left.6 g, h, i\right)$, respectively.

\section{Regression analysis (polynomial cubic) between $C: N, C: P$, and $N: P$ ratios with the stand characteristics}

The results showing the values of regression analysis between $\mathrm{C}: \mathrm{N}, \mathrm{C}: \mathrm{P}$, and $\mathrm{N}: \mathrm{P}$ ratios with different stand characteristics are given in the Fig. 7. The results highlighted that C:N and C:P (Fig. 7a,b) showed a maximum value of 11.79 and 3.69 with maximum value of $700\left(\mathrm{ha}^{-1}\right)$ stand density and with minimum value of 9.04 and 2.86 at stand densities of $248\left(\mathrm{ha}^{-1}\right)$ and $312\left(\mathrm{ha}^{-1}\right)$, respectively, but N:P (Fig. 7c) showed a different pattern from $\mathrm{C}: \mathrm{N}$ and $\mathrm{C}: \mathrm{P}$ with the maximum and minimum value of 0.35 and 0.26 with respective stand density of $572\left(\mathrm{ha}^{-1}\right)$ and $312\left(\mathrm{ha}^{-1}\right)$. Similarly, maximum and minimum value of $\mathrm{C}: \mathrm{N}$ and $\mathrm{C}: \mathrm{P}$ and $\mathrm{N}: \mathrm{P}$ (Fig. 7d,e,f) were found at their respective maximum and minimum stand basal areas of $18.28\left(\mathrm{ha}^{-1}\right)$ and $8.04\left(\mathrm{ha}^{-1}\right)$. Fig. $7 g, h, i$ highlighted the regression analysis between $\mathrm{C}: \mathrm{N}, \mathrm{C}: \mathrm{P}$ and $\mathrm{N}: \mathrm{P}$ with total biomass carbon and figured out the maximum and minimum value of $11.79,9.04$ and 3.69, 2.86 and $0.35,0.26$ with their respective total biomass carbon of $30.63\left(\mathrm{t} \mathrm{ha}^{-1}\right), 12.44\left(\mathrm{ha}^{-1}\right)$ and $30.63\left(\mathrm{t} \mathrm{ha}^{-1}\right)$, $25.78\left(\mathrm{t} \mathrm{ha}^{-1}\right)$ and $28.52\left(\mathrm{t} \mathrm{ha}^{-1}\right), 25.78$, respectively.

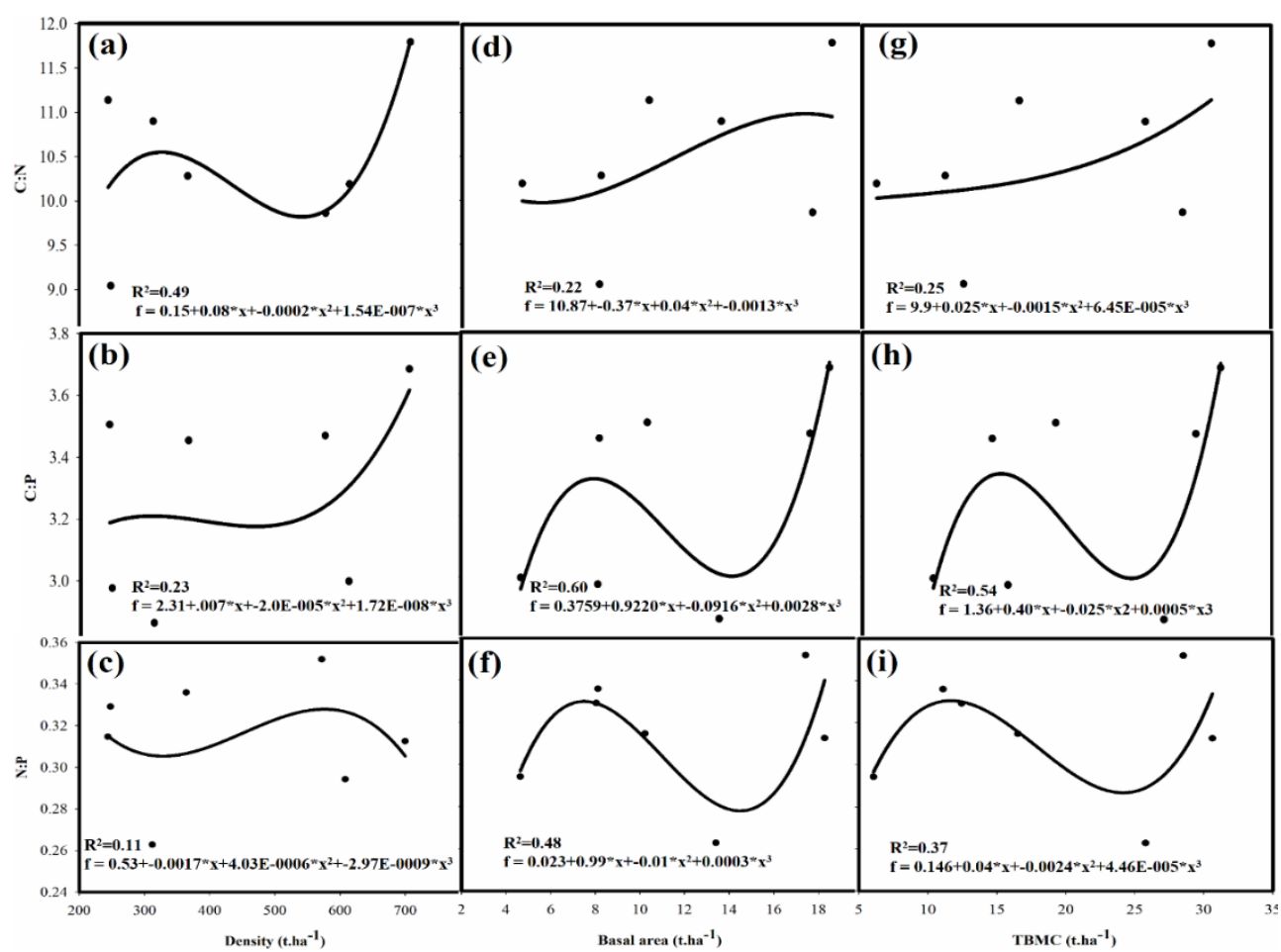

Figure 7. Regression analysis (Polynomial Cubic) of C:N, C:P, and N:P with stand density (a, $b, c)$, stand basal area $(d, e, f)$ and total biomass carbon $(g, h, i),(p<0.01, n=7)$ 


\section{Discussion}

\section{Effect of soil depth on soil TSOC, TN, and TP storage and concentration}

Variation in soil TSOC, TN, and TP storage and concentration are the key indicators of changes in soil fertility and long-term ecosystem sustainability and management and variation in soil organic carbon concentration have consequences for the influence of land cover change on atmospheric carbon dioxide concentration and global warming (Ross et al., 1999). Our Results show that depth and soil nutrients are significantly correlated and the nutrients concentration decreases significantly with depth increment under scots pine plantation (Pinus sylvestris var mongolica) (Fig. 4). These results match the statement of some previous observations in arid and semi-arid regions of China (Hu et al., 2008; Chen et al., 2010). There are many reasons affecting the variation of TSOC, TN, and TP concentration along the soil depth. For instance, the balance between inputs and outputs can affect the concentration of these nutrients status, and variation in the amount and quality of plant litter contribution with land cover change may be important factors to change the ecosystem practices and eventually ecosystem properties (McKinley et al., 2008). Soil disturbances during plantation establishment in the area may also result in the faster mineralization of soil nutrients and increase the potential for nutrients loss (Guo and Gifford, 2002). The plant community, species composition, topography and soil texture can also alter the soil nutrients status (Guo and Gifford, 2002; Paul et al., 2002; Archer et al., 2004) and the coarse soil in this region might have limited soil carbon accumulation after the establishment of Scots pine plantation (Richter et al., 1999). TSOC concentration decreased with depth because of the unavailability of easily decomposed organic matter in the deep soil (Liang et al., 2010) and the soil carbon mineralization is mostly controlled by easily available decomposable soil organic carbon. Similarly, the soil nutrient concentration and availability in the top soil are mostly observed after planation of arid and semi-arid sites (Billings, 2006; McKinley et al., 2008). Furthermore, Zeng et al. (2009) reported that after conversion of arid and semi-arid regions of China to Mongolian Scots pine plantation, the concentration and mineralization of soil nutrients increased in the upper soil because of increased annual root biomass and litter input and its decomposition in the upper soil as compared to the grassland and Savana.

The concentration and seasonal distribution of soil total carbon is governed by the size and quantity of soil microbial biomass (Wei et al., 2009). Soil TSOC and the depth increment significantly correlated (Fig. 4a), suggests that soil depth was an important factor influencing the soil TSOC in our study area. Difference in the amount of soil organic matter added to the soil under forest vegetation can affect the soil organic carbon (Chen et al., 2010). The significant higher TSOC concentration in the top soil of Mongolian pine plantation reflected the greater amount and availability of organic matter accumulated in the top soil and the same was reported for pine plantation (Zeng et al., 2009). Similarly, some other studies also concluded that with the development of plantation on arid and semi-arid regions, the more TSOC and nutrients are being released from accumulation and decomposition of microbial biomass and litter input into the top soil, which could result in higher TSOC and related nutrients concentration in the upper soil surface (Cleveland and Liptzin, 2007; Li et al., 2017b). Although, initially plantation consistently resulted in the loss of some SOC from top soil in this region by altering the soil properties, but later on with the development of plantation, the $\mathrm{C}$ concentration gradually increased (Chen et al., 2010). 
Our results for total soil nitrogen concentration was consistent with the previously reported for Keerqin sandy land (Chen et al., 2006; Holst et al., 2007; Zeng et al., 2009). Soil depth, litter fall, land cover change and sampling season has a valid interaction with the TN storage and can significantly alter the available nitrogen concentration (Fig. 4b), consistent with many other studies of soil nitrogen changes following land cover changes (Owen et al., 2003; Parfitt et al., 2003; Zeng et al., 2009).

Our results (Fig. 4c) demonstrated that afforestation in semiarid region of China significantly reduced TP stocks, which is consistent with the previously reported global scale study stating that the TP concentration below $20 \mathrm{~cm}$ significantly decreased (Deng et al., 2017). As it has also been explained in many studies that the microbial biomass, mineralization of organic $\mathrm{P}$ and phosphate activities and susceptibility of organic matter to microbial attack and enzymes hydrolysis take place in top surface and decreases gradually as the depth increases (Magid et al., 1996). The same phenomenon was also demonstrated for Mongolian pine plantation (Zhao et al., 2007). In our study, the pH level is low in the top soil (Fig. 3a), which may also improve organic $\mathrm{P}$ mineralization by increasing the susceptibility of organic P to enzyme hydrolysis in the top soil, and the same was also reported for Mongolian scots pine in Keerqin sandy land of China (Zhao et al., 2007). The decrease in the concentration of TSOC, TN, and TP with increase in the soil depth under Mongolian scots pine can be attributed to the development of juvenile plantation that require more nutrients in top soil than leaching down as the same was reports in other studies too (Laclau et al., 2003; Zhao et al., 2007).

\section{Effect of depth increment on soil nutrients stoichiometry}

The soil mean $\mathrm{P}$ and $\mathrm{N}$ concentrations and its stoichiometry in our study is lower than the global level (Zhang et al., 2005), may be because of weathering and soil erosion in the in Mongolian Scots pine (Pinus sylvestris var. mongolica) plantation forests in semiarid areas of China. It can also be attributed to the lower $\mathrm{P}$ concentration in China soil than global value (Han et al., 2005). Similarly, the C: N and C: P stoichiometry and soil $\mathrm{C}$ concentration was significantly higher than soil $\mathrm{N}$ and $\mathrm{P}$ concentration and stoichiometry, indicating that coniferous forests store more $\mathrm{C}$, consistent with other studies for coniferous forests (Güsewell and Koerselman, 2002; Zeng et al., 2009). In addition, our study findings reveal higher $\mathrm{C}$ : $\mathrm{N}$ ratio than $\mathrm{C}: \mathrm{P}$ and $\mathrm{N}: \mathrm{P}$, which might be the result of higher human influence in the plantation, and the same was reported (Zhang et al., 2017). The soil nutrient concentrations and stoichiometric ratios in our study were significantly correlated with depth increment, consistent with a previous study (Zeng et al., 2016), due to a large amount of the nutrients in litter and deadwood were released into the soil as litter is a main source of soil nutritional elements.

This study demonstrated the same trend of $\mathrm{C}: \mathrm{N}>\mathrm{C}: \mathrm{P}>\mathrm{N}: \mathrm{P}$, which is also reported in other studies (Tian et al., 2010; Ouyang et al., 2017). Different studies (Li, 2012; Ren et al., 2016) showed a different CNP rations along the soil profile increment because of difference in land use practices and management system, but followed the same trend as presented in this study. Li et al. (2012) studied that difference in $\mathrm{C}: \mathrm{N}: \mathrm{P}$ ratios might be the result of different vegetation cover and land use management practices. Zhao et al. (2015) demonstrated that forest types and plant communities can effect soil nutrients stoichiometry. Similarly, Fan et al. (2015) concluded that together, soil depth and successional stage significantly influence soil CNP stoichiometry. Globally, a wellbalanced CNP stoichiometry for top 0-10 cm profile is 186:13:1 (Cleveland and Liptzin, 2007; Wang, 2014), while a general CNP stoichiometry for rich organic nutrients soil for 
0-10 $\mathrm{cm}$ depth is 134:9:1 and for the entire soil depth i.e., $0-250 \mathrm{~cm}$ is $60: 5: 1$ in China (Tian et al., 2010). In our study, the average $C: N: P$ ratio was $10.53: 3.24: 0.32$ for $0-100 \mathrm{~cm}$ soil depth, while for $0-20 \mathrm{~cm}$ and $20-40 \mathrm{~cm}$ the $\mathrm{C}: \mathrm{N}: \mathrm{P}$ ratios were 10.44:3.2:0.36 and 9.80:3.22:0.33, respectively. Our estimates for C:N:P ratios are lower than the estimated average value of $\mathrm{C}: \mathrm{N}: \mathrm{P}$ as reported above. Our $\mathrm{C}: \mathrm{N}: \mathrm{P}$ value for $0-20 \mathrm{~cm}$ was much lower than reported for China soil (Tian et al., 2010). These differences might be due to the soil samples containing more humidified litter in Tian et al. (2010), resulting in relatively higher $\mathrm{C}: \mathrm{N}: \mathrm{P}$ ratios compared to our estimates. In this study the average value for $\mathrm{C}: \mathrm{N}$ ratio was nearly $>10$, and a low $(<25) \mathrm{C}: \mathrm{N}$ ratio suggests that the soil organic matter accumulation is slower than its decomposition (Yang et al., 2007b).

\section{Relationship between soil nutrients and stand characteristics}

Stand characteristics and soil property has an encouraging interaction and soil nutrients can vary along stand characteristic variations (Jiang et al., 2017; Xu et al., 2018). We investigated that the stand density has a significant effect on the biomass carbon production that can bring variation in TSOC, TN, and TP concentration and storage. Our results show that TSOC, TN, and TP followed an increased pattern with increase in stand characteristics (stand density, basal area and total biomass carbon) up to some extent and then dropped (Fig. 6). This difference in nutrients distribution and fluxes among plantations along different stand characteristics have implications for management of successive Pinus sylvestris var mongolica plantations forests in the study area in order to maximize nutrients concentration and cycling. It has been investigated that stand density has an impacts on soil nutrients and can alter the amount of soil TSOC, TN, and TP concentration (Ma et al., 2007) and the stand characteristics like, Density, basal area and total aboveground biomass have a key role in soil nutrients concentration in plantation forests because of the litter fall and fast decomposition rate (Little and Shainsky, 1995; Sheng and Yang, 1997). Our study findings are consistent with previous study (Ma et al., 2007), stating that the soil nutrients decreased with the competition among Chinese fir plantation increased. It could also be explained that with highest basal area, density and biomass, higher accumulation of litter with lower decomposition rate due unavailability of sun light and proper aeration (Jiang et al., 2017). However, the mean TSOC and TP concentration in our results were higher compared to Jiang et al. (2017). It could be attributed that there is more SOC and $\mathrm{P}$ input (litter and deadwood decomposition) from plants and rapid turnover of litter (Tong et al., 2012; Yang et al., 2014). In contrast, Yang et al. (2014) attributed higher soil TSOC and TN but lower TP concentration in broadleaved deciduous forest and our study shows high TSOC and TP as compared to TN. These differences might be due to the differences in forest nature and topography because Yang et al. (2014) studied a broadleaved plantation while we studied a Pine plantation forests. Polynomial regression analysis showed that the variations in soil TSOC, $\mathrm{TN}$, and TP in the plantation investigated were positively and significantly correlated with the stand characteristics, including stand density, basal area and total biomass carbon. This shows a potential influence of stand characteristics on the variation of soil nutrients in the forests (Xia et al., 2015). Yuan et al. (2013) studied that the basal area and canopy structure can alter the soil nutrients concentration because it may affect the temperature and soil moisture contents of forest floor soil, which are important factors affecting the litter and deadwood decomposition process. Similarly, our results demonstrated a high value of C:N but slightly low C:P and N:P with high stand density, basal area and total biomass carbon (Fig. 7). It could be attributed that in soil, mostly TP contents is available 
in inorganic forms, that show little or no variation along the stand characteristics and may lead to the high ratios of C:N (Jiang et al., 2017). Soil nutrients stoichiometric ratios didn't show any good correlation along different stand characteristics (Fig. 7) might be because that stoichiometry is a combine result of multiple activities, like elemental uptake, excretion and storage, thus it cannot fully specify the ability of plants to achieve limiting resources. Furthermore, it has been investigated that stoichiometric and elemental compositions of vegetation vary significantly along stand characteristics (Yang et al., 2011; Liang et al., 2018). However, there might be other factors like, over grazing, land use change practices etc., that might also alter the soil nutrients and its stoichiometry.

\section{Conclusion}

Our findings support the hypothesis that depth increment and stand characteristics have a significant effect on TSOC, TN, and TP storage, stoichiometry, and concentration. Stand characteristics like stand density, basal area, and total biomass carbon could significantly affect the TSOC, TN, and TP concentration and storage. Furthermore, soil $\mathrm{C}: \mathrm{N}$ and $\mathrm{C}: \mathrm{P}$ ratios increase more as compared to $\mathrm{N}: \mathrm{P}$ with depth, showing the organic $\mathrm{N}$ and $\mathrm{P}$ limitation for plant growth in the region. This study is the first attempt to indicate the TSOC, TN, TP and its stoichiometry at the vertical profile scale and along the stand characteristics. Similarly, this study will provide useful information for sustainable management of Mongolian Scots Pine plantation forest. For future, it is strongly recommended to conduct more research studies on climate change, soil nutrients dynamics and growth response relationship.

Acknowledgements. We are thankful to the National Key Research and Development Program of ChinaLand desertification formation mechanism and ecological restoration mechanism in the sandstorm source area of Beijing, Tianjin and Hebei (2016YFC0500801), The National Natural Science Foundation of ChinaDendroecological study on the tree growth dynamic and their climate adaptability of natural Mongolia Pine forest modulated by competitions in Hulunbuir sandland (31670715), The National Natural Science Foundation of China-Monitoring near-surface thermal property and evaporation using the heat-pulse technique: correcting the effects of soil heterogeneity (41701249).

\section{REFERENCES}

[1] Ågren, G. I., Wetterstedt, J. M., Billberger, M. F. (2012): Nutrient limitation on terrestrial plant growth-modeling the interaction between nitrogen and phosphorus. - New Phytologist 194(4): 953-960.

[2] Ahmad, A., Liu, Q. J., Marwat, K. B., Shah, S. H., Amir, M. U., Mannan, A. B. (2018): Tree distribution pattern, growing stock characteristics and carbon mitigation potential of different forests ecosystems in kumrat, hindukush region of northern pakistan. - Pakistan Journal of Botany 51(6): 2185-2194.

[3] Archer, S., Boutton, T. W., McMurtry, C. (2004): Carbon and nitrogen accumulation in a savanna landscape: field and modeling perspectives. - In: Shiyomi, M. (ed.) Global environmental change in the ocean and on land. TERRAPUB, pp. 359-373.

[4] Billings, S. (2006): Soil organic matter dynamics and land use change at a grassland/forest ecotone. - Soil Biology and Biochemistry 38(9): 2934-2943.

[5] Bremner, J. M. (1996): Nitrogen-total. Methods of soil analysis. - Part 3 Chemical methods 5: 1085-1121. 
[6] Cao, Y., Chen, Y. (2017): Coupling of plant and soil C: N: P stoichiometry in black locust (Robinia pseudoacacia) plantations on the Loess Plateau, China. - Trees 31(5): 1559-1570.

[7] Chen, F. S., Zeng, D. H., Zhou, B., Singh, A. N., Fan, Z. P. (2006): Seasonal variation in soil nitrogen availability under Mongolian pine plantations at the Keerqin Sand Lands, China. - Journal of arid environments 67(2): 226-239.

[8] Chen, C. R., Condron, L. M., Xu, Z. H. (2008): Impacts of grassland afforestation with coniferous trees on soil phosphorus dynamics and associated microbial processes: a review. - Forest Ecology and Management 255(3-4): 396-409.

[9] Chen, F. S., Zeng, D. H., Fahey, T. J., Liao, P. F. (2010): Organic carbon in soil physical fractions under different-aged plantations of Mongolian pine in semi-arid region of Northeast China. - Applied Soil Ecology 44(1): 42-48.

[10] Cleveland, C. C., Liptzin, D. (2007): C: N: P stoichiometry in soil: is there a "Redfield ratio" for the microbial biomass? - Biogeochemistry 85(3): 235-252.

[11] Deng, L., Yan, W., Zhang, Y., Shangguan, Z. (2016): Severe depletion of soil moisture following land-use changes for ecological restoration: evidence from northern China. Forest Ecology and Management 366: 1-10.

[12] Deng, Q., McMahon, D. E., Xiang, Y., Yu, C. L., Jackson, R. B., Hui, D. (2017): A global meta-analysis of soil phosphorus dynamics after afforestation. - New Phytologist 213(1): 181-192.

[13] Fan, H., Wu, J., Liu, W., Yuan, Y., Hu, L., Cai, Q. (2015): Linkages of plant and soil C: N: $\mathrm{P}$ stoichiometry and their relationships to forest growth in subtropical plantations. - Plant and Soil 392(1-2): 127-138.

[14] Guo, L. B., Gifford, R. M. (2002): Soil carbon stocks and land use change: a meta-analysis. - Global change biology 8(4): 345-360.

[15] Güsewell, S., Koerselman, W. (2002): Variation in nitrogen and phosphorus concentrations of wetland plants. - Perspectives in Plant Ecology, Evolution and Systematics 5(1): 37-61.

[16] Han, W., Fang, J., Guo, D., Zhang, Y. (2005): Leaf nitrogen and phosphorus stoichiometry across 753 terrestrial plant species in China. - New phytologist 168(2): 377-385.

[17] Holst, J., Liu, C., Brüggemann, N., Butterbach-Bahl, K., Zheng, X., Wang, Y., Han, S., Yao, Z., Yue, J., Han, X. (2007): Microbial N turnover and N-oxide (N 2 O/NO/NO 2) fluxes in semi-arid grassland of Inner Mongolia. - Ecosystems 10(4): 623-634.

[18] Hoover, C. M. (ed.) (2008): Field measurements for forest carbon monitoring: a landscapescale approach. - Springer Science \& Business Media.

[19] Hu, Y. L., Zeng, D. H., Fan, Z. P., Chen, G. S., Zhao, Q., Pepper, D. (2008): Changes in ecosystem carbon stocks following grassland afforestation of semiarid sandy soil in the southeastern Keerqin Sandy Lands, China. - Journal of Arid Environments 72(12): 21932200.

[20] Jiang, F., Wu, X., Xiang, W., Fang, X., Zeng, Y., Ouyang, S., Lei, P., Deng, X., Peng, C. (2017): Spatial variations in soil organic carbon, nitrogen and phosphorus concentrations related to stand characteristics in subtropical areas. - Plant and Soil 413(1-2): 289-301.

[21] Kim, H. Y., Lim, S. S., Kwak, J. H., Lee, D. S., Lee, S. M., Ro, H. M., Choi, W. J. (2011): Dry matter and nitrogen accumulation and partitioning in rice (Oryza sativa L.) exposed to experimental warming with elevated CO2. - Plant and Soil 342(1-2): 59-71.

[22] Laclau, J. P., Deleporte, P., Ranger, J., Bouillet, J. P., Kazotti, G. (2003): Nutrient dynamics throughout the rotation of Eucalyptus clonal stands in Congo. - Annals of Botany 91(7): 879-892.

[23] Li, Y., Wu, J., Liu, S., Shen, J., Huang, D., Su, Y., Wei, W., Syers, J. K. (2012): Is the C: $\mathrm{N}$ : P stoichiometry in soil and soil microbial biomass related to the landscape and land use in southern subtropical China? - Global Biogeochemical Cycles 26(4).

[24] Li, H., Crabbe, M. J. C., Xu, F., Wang, W., Niu, R., Gao, X., Zhang, P., Chen, H. (2017a): Seasonal variations in carbon, nitrogen and phosphorus concentrations and C: N: P stoichiometry in the leaves of differently aged Larix principis-rupprechtii Mayr. plantations. - Forests 8(10): 373. 
[25] Li, Y., Chen, Y., Wang, X., Niu, Y., Lian, J. (2017b): Improvements in soil carbon and nitrogen capacities after shrub planting to stabilize sand dunes in China's Horqin Sandy Land. - Sustainability 9(4): 662.

[26] Liang, J., Wang, X. A., Yu, Z. D., Dong, Z. M., Wang, J. C. (2010): Effects of vegetation succession on soil fertility within farming-plantation ecotone in Ziwuling Mountains of the Loess Plateau in China. - Agricultural Sciences in China 9(10): 1481-1491.

[27] Liang, X., Liu, S., Wang, H., Wang, J. (2018): Variation of carbon and nitrogen stoichiometry along a chronosequence of natural temperate forest in northeastern China.Journal of Plant Ecology 11(3): 339-350.

[28] Little, S. N., Shainsky, L. J. (1995): Biomass and nutrient distributions in central Oregon second-growth ponderosa pine ecosystems. - Res. Pap. PNW-RP-481. Portland, OR: US Department of Agriculture, Forest Service, Pacific Northwest Research Station 17: 481.

[29] Lorenz, K., Lal, R. (2010): The importance of carbon sequestration in forest ecosystems. In: Carbon Sequestration in Forest Ecosystems. Springer, Dordrecht, pp. 241-270.

[30] Ma, X., Heal, K. V., Liu, A., Jarvis, P. G. (2007): Nutrient cycling and distribution in different-aged plantations of Chinese fir in southern China. - Forest Ecology and Management 243(1): 61-74.

[31] Magid, J., Tiessen, H., Condron, L. M. (1996): Dynamics of organic phosphorus in soils under natural and agricultural ecosystems. - In: Humic substances in terrestrial ecosystems. Elsevier Science BV pp. 429-466.

[32] McKinley, D. C., Norris, M. D., Blair, J. M., Johnson, L. C. (2008): Altered ecosystem processes as a consequence of Juniperus virginiana L. encroachment into North American tallgrass prairie. - In: Western North American Juniperus Communities. Springer, New York, NY pp. 170-187.

[33] Nelson, D. W., Sommers, L. (1983): Total carbon, organic carbon, and organic matter. Methods of soil analysis. - Part 2 Chemical and microbiological properties 9: 539-579.

[34] Ouyang, S., Xiang, W., Gou, M., Lei, P., Chen, L., Deng, X., Zhao, Z. (2017): Variations in soil carbon, nitrogen, phosphorus and stoichiometry along forest succession in southern China. - Biogeosciences Discussions, pp. 1-27.

[35] Owen, J. S., Wang, M. K., Sun, H. L., King, H. B., Wang, C. H., Chuang, C. F. (2003): Comparison of soil nitrogen mineralization and nitrification in a mixed grassland and forested ecosystem in central Taiwan. - Plant and soil 251(1): 167-174.

[36] Parfitt, R. L., Scott, N. A., Ross, D. J., Salt, G. J., Tate, K. R. (2003): Land-use change effects on soil $\mathrm{C}$ and $\mathrm{N}$ transformations in soils of high $\mathrm{N}$ status: comparisons under indigenous forest, pasture and pine plantation. - Biogeochemistry 66(3): 203-221.

[37] Paul, K. I., Polglase, P. J., Nyakuengama, J. G., Khanna, P. K. (2002): Change in soil carbon following afforestation. - Forest ecology and management 168(1-3): 241-257.

[38] Ren, C., Zhao, F., Kang, D., Yang, G., Han, X., Tong, X., Feng, Y., Ren, G. (2016): Linkages of C: N: P stoichiometry and bacterial community in soil following afforestation of former farmland. - Forest Ecology and Management 376: 59-66.

[39] Richter, D. D., Markewitz, D., Trumbore, S. E., Wells, C. G. (1999): Rapid accumulation and turnover of soil carbon in a re-establishing forest. - Nature 400(6739): 56-58.

[40] Ross, D. J., Tate, K. R., Scott, N. A., Feltham, C. W. (1999): Land-use change: effects on soil carbon, nitrogen and phosphorus pools and fluxes in three adjacent ecosystems. - Soil biology and biochemistry 31(6): 803-813.

[41] Sardans, J., Rivas-Ubach, A., Peñuelas, J. (2011): Factors affecting nutrient concentration and stoichiometry of forest trees in Catalonia (NE Spain). - Forest Ecology and Management 262(11): 2024-2034.

[42] Sheng, W., Yang, C. (1997): Research on effect of ameliorating soil properties by undergrowth vegetation of China fir. - Acta Ecologica Sinica 17(4): 377-385.

[43] Song, L., Zhu, J., Li, M., Zhang, J., Lv, L. (2016): Sources of water used by Pinus sylvestris var. mongolica trees based on stable isotope measurements in a semiarid sandy region of Northeast China. - Agricultural water management 164: 281-290. 
[44] Tian, H., Chen, G., Zhang, C., Melillo, J. M., Hall, C. A. (2010): Pattern and variation of C: N: P ratios in China's soils: a synthesis of observational data. - Biogeochemistry 98(13): $139-151$.

[45] Tong, J., Xiang, W., Liu, C., Lei, P., Tian, D., Deng, X., Peng, C. (2012): Tree species effects on fine root decomposition and nitrogen release in subtropical forests in southern China. - Plant Ecology \& Diversity 5(3): 323-331.

[46] Wang, W., Sardans, J., Zeng, C., Zhong, C., Li, Y., Peñuelas, J. (2014): Responses of soil nutrient concentrations and stoichiometry to different human land uses in a subtropical tidal wetland. - Geoderma 232: 459-470.

[47] Wei, X., Shao, M., Fu, X., Horton, R., Li, Y., Zhang, X. (2009): Distribution of soil organic $\mathrm{C}, \mathrm{N}$ and $\mathrm{P}$ in three adjacent land use patterns in the northern Loess Plateau, China. Biogeochemistry 96(1-3): 149-162.

[48] Wright, I. J., Westoby, M. (2003): Nutrient concentration, resorption and lifespan: leaf traits of Australian sclerophyll species. - Functional Ecology 17(1): 10-19.

[49] Xia, S. W., Chen, J., Schaefer, D., Detto, M. (2015): Scale-dependent soil macronutrient heterogeneity reveals effects of litterfall in a tropical rainforest. - Plant and Soil 391(1-2): 51-61.

[50] Xing, J., Zheng, C. Y., Feng, C. Y., Zeng, F. X. (2017): Change of growth characters and carbon stocks in plantations of Pinus sylvestris var. mongolica in Saihanba, Hebei, China. - Chinese Journal of Plant Ecology 41(8): 840.

[51] Xu, C., Xiang, W., Gou, M., Chen, L., Lei, P., Fang, X., Deng, X., Ouyang, S. (2018): Effects of forest restoration on soil carbon, nitrogen, phosphorus, and their stoichiometry in Hunan, southern China. - Sustainability 10(6): 1874.

[52] Yang, L., Huang, J., Yang, H., Dong, G., Liu, H., Liu, G., Zhu, J., Wang, Y. (2007a): Seasonal changes in the effects of free-air $\mathrm{CO} 2$ enrichment (FACE) on nitrogen (N) uptake and utilization of rice at three levels of N fertilization. - Field Crops Research 100(2-3): 189-199.

[53] Yang, L., Wang, Y., Huang, J., Zhu, J., Yang, H., Liu, G., Liu, H., Dong, G., Hu, J. (2007b): Seasonal changes in the effects of free-air CO2 enrichment (FACE) on phosphorus uptake and utilization of rice at three levels of nitrogen fertilization. - Field crops research 102(2): 141-150.

[54] Yang, Y., Luo, Y. (2011): Carbon: nitrogen stoichiometry in forest ecosystems during stand development. - Global Ecology and Biogeography 20(2): 354-361.

[55] Yang, J. K., Zhang, J. J., Yu, H. Y., Cheng, J. W., Miao, L. H. (2014): Community composition and cellulase activity of cellulolytic bacteria from forest soils planted with broad-leaved deciduous and evergreen trees. - Applied microbiology and biotechnology 98(3): 1449-1458.

[56] Yuan, Z., Gazol, A., Lin, F., Ye, J., Shi, S., Wang, X., Wang, M., Hao, Z. (2013): Soil organic carbon in an old-growth temperate forest: spatial pattern, determinants and bias in its quantification. - Geoderma 195: 48-55.

[57] Zeng, D., Hu, Y., Chang, S., Fan, Z. (2009): Land cover change effects on soil chemical and biological properties after planting Mongolian pine (Pinus sylvestris var. mongolica) in sandy lands in Keerqin, northeastern China. - Plant and Soil 317(1-2): 121-133.

[58] Zeng, Q., Li, X., Dong, Y., An, S., Darboux, F. (2016): Soil and plant components ecological stoichiometry in four steppe communities in the Loess Plateau of China. Catena 147: 481-488.

[59] Zhang, C., Tian, H., Liu, J., Wang, S., Liu, M., Pan, S., Shi, X. (2005): Pools and distributions of soil phosphorus in China. - Global biogeochemical cycles 19(1).

[60] Zhang, G., Zhang, P., Peng, S., Chen, Y., Cao, Y. (2017): The coupling of leaf, litter, and soil nutrients in warm temperate forests in northwestern China. - Scientific reports 7(1): 11754 . 


$$
-1751-
$$

[61] Zhang, X., Zhang, X., Han, H., Shi, Z., Yang, X. (2019): Biomass Accumulation and Carbon Sequestration in an Age-Sequence of Mongolian Pine Plantations in Horqin Sandy Land, China. - Forests 10(2): 197.

[62] Zhao, Q., Zeng, D. H., Lee, D. K., He, X. Y., Fan, Z. P., Jin, Y. H. (2007): Effects of Pinus sylvestris var. mongolica afforestation on soil phosphorus status of the Keerqin Sandy Lands in China. - Journal of Arid Environments 69(4): 569-582.

[63] Zhao, F., Sun, J., Ren, C., Kang, D., Deng, J., Han, X., Ren, G. (2015): Land use change influences soil C, N, and P stoichiometry under 'Grain-to-Green Program' in China. Scientific Report 5: 10195. 